\title{
ランダムウォーク粒子追跡法による取水井の 溶質捕獲領域とトラベルタイム推定 \\ RANDOM WALK PARTICLE TRACKING APPROACH TO ESTIMATE SOLUTE CAPTURE ZONE OF PUMPING WELL AND SOLUTE TRAVEL TIME
}

\author{
井上一哉 ${ }^{1} \cdot$ 倉澤智樹 $^{2} \cdot$ 田中勉 ${ }^{3}$ \\ Kazuya INOUE, Tomoki KURASAWA and Tsutomu TANAKA \\ 1 正会員 博士(農学) 神戸大学准教授 大学院農学研究科（干657-8501 神戸市灘区六甲台町1-1） \\ 2 学生会員 神戸大学大学院生大学院農学研究科（广657-8501 神戸市灘区六甲台町1-1） \\ 3 正会員 農博 神戸大学教授大学院農学研究科（广657-8501 神戸市灘区六甲台町1-1）
}

\begin{abstract}
This paper presents a stochastic methodology using random walk particle tracking to estimate solute capture zones in a pumping well. Realizations of heterogeneous aquifer are represented as randomly correlated hydraulic conductivity and partition coefficient fields. By superposition of all solute capture zones, probability distributions are obtained that describe the probability of a certain grid space from which a solute particle will reach the well and the corresponding travel time. Proposed methodology demonstrated that a larger pumping rate and less heterogeneity of hydraulic conductivity lead to the decrease of the uncertainty factor, which is defined by the ratio of the area having the probability of non-zero and less than 1 to the area having the probability of 1 . Chemical heterogeneity related to the retardation factor distribution has little influence on the both spatial distributions of solute capture zone and travel time.
\end{abstract}

Key Words: random walk particle tracking, solute capture zone, solute travel time, pumping well, heterogeneous aquifer

\section{1. 緒論}

地下水は地下空間に賦存する貴重な水資源であると同 時に污染に対寸る脆弱性を有している．有害物質が帯水 層へ侵入すると長期の浄化時間，莫大な浄化費用を要し， ヒトの健康や生活環境への悪影響が䀣念されることから, 地下水の水量・水質管理は重要な課題である. 污染地下 水の浄化において, 地下水揚水処理は高い頻度で実行さ れる策であり，既定の揚水量条件で污染物質を回収でき る範囲や回収に要する時間の見積もりを課題とする1). 一 方, 地下水の飲用水利用においては, 污染物質が取水井 一流入しない範囲の推定や不慮の事故を想定した污染源 から取水井に至る物質のトラベルタイムを推定すること が望まれる。したがって，揚水の目的に関わらず，取水 井を用いて帯水層から地下水を汲み上げる際には，污染 物質の流入範囲や到達予想時間を推定することとなる2). 地下水揚水の際に地下水が取水井一流入する領域，す なわち集水域に関寸る事例 ${ }^{3)}$ に比べると，取水井に污染 物質が流入する領域を確率的に推定する研究はかなり少 ない4)。また，溶質の移流成分のみを対象とする事例2)5 が多く, 分散の影響はあまり考慮されていない, 井上
ら ${ }^{6)}$ は粒子追跡法を用いて集水域の推定と取水井での溶 質回収に関して検討しているが，帯水層に存在する污染 物質を捕獲可能な領域については十分に議論していない.

これらの点を踏まえて本研究では, ランダムウォーク 粒子追跡法を用いて, 地下水揚水に伴い取水井に溶質が 流入する領域を確率的に推定する方法を考案した，提案 手法を揚水量条件や不均質条件を変えた透水場に適用寸 ることで，想定する状況に応じた溶質の取水井への到達 確率や到達に至るトラベルタイムについて検討した。 な お, 本研究では, 地下水污染物質の溶質部分を輸送の対 象とし, 地下水揚水の際に地下水が取水井一流入寸る領 域を集水域と称する ${ }^{1}$ 点を反映して, 取水井に溶質が流 入する領域を“集粒域”と定義する.

\section{2. 集粒域の推定方法}

\section{(1) 解析対象領域と模擬透水係数分布}

本研究では, オランダ国デンハーグ市近郊にあるサ イトを対象として, 図-1に示すように, 南北方向を $x$ 軸, 東西方向を $y$ 軸に設定し, $270 \mathrm{~m} \times 160 \mathrm{~m}$ の二次元 


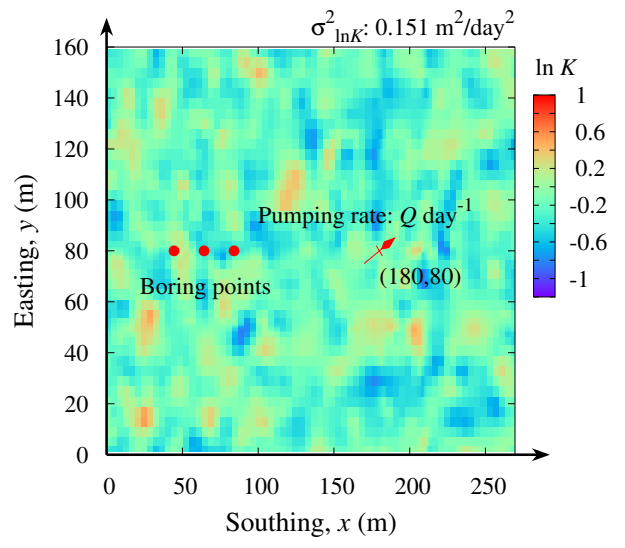

図-1 解析対象領域の概略と透水係数分布の例

領域を設けた．対象サイトは $x$ 軸の正方向への領域流 れ, 約 $20 \mathrm{~m}$ の帯水層厚さを有する被圧帯水層であり, $(x, y)=(180 \mathrm{~m}, 80 \mathrm{~m})$ の位置に取水井がある ${ }^{7}$.

図-1に示すように，サイト内には3箇所のボーリング孔 にて深さ方向の透水係数が測定されており，透水係数分 布の幾何平均と幾何分散 $\sigma_{\ln K}^{2}$ はそれぞれ $0.821 \mathrm{~m} /$ day $0.151 \mathrm{~m}^{2} / \mathrm{day}^{2}$, 間隙率は 0.35 である. 便宜上, 本研究で は幾何分散のことを不均質度と称する．透水係数の空間 分布をモデル化するにあたり，対象サイトの測定は局所 的であり, 透水係数の空間分布を唯一に定めるのは極め て難しい状況にある. そのため, 対象場の透水係数は対 数正規分布に従い, 特定のバリオグラムに従って分布す ると仮定した上で, 領域内に $10^{3}$ 個のソース点をランダム 抽出し, 各点に既定の対数正規分布に従う透水係数をラ ンダム生成した ${ }^{8)}$. また, 対象領域の分割要素の透水係数 をソース点の透水係数からブロッククリギング予測 ${ }^{9}$ し， 透水係数の不均質性を有寸る場（リアライゼーション） を生成した. 領域規模や推定対象の類似した研究2)10) 参考にして, リアライゼーション数を 30 に設定し, 同一 の不均質性を有する 30 種類の場を生成した。このとき, $0.5 \mathrm{~m} \sim 4 \mathrm{~m}$ の有限要素を採用したことから, 要素サイ ズの影響は微小と考えられる。また，透水係数データが 少ないため, 文献711)を参考に, 相関長入を $13 \mathrm{~m}$, シル にはサイトの幾何分散を設定 ${ }^{7)} し$ ，透水係数の空間相関 は等方として次式の指数型バリオグラム $\gamma$ を採用した.

$$
\gamma(h)=\sigma_{\ln K}^{2}(1-\exp (h / \lambda))
$$

ここに, $h$ は観測点間距離である. 透水係数の空間分布 例を図-1に示す.

\section{（2）浸透流解析}

被圧帯水層内の完全貫入井での揚水を考慮して, 定常 流状態にある浸透流方程式は次式で表される ${ }^{12)}$.

$$
\nabla \cdot(K(\boldsymbol{x}) \nabla h)=Q
$$

ここに, $h$ はピエゾ水頭, $\boldsymbol{x}$ は位置ベクトル, $K(\boldsymbol{x})$ は透水 係数テンソルであり, 等方性を仮定した. また， $Q$ は揚 水量であり, サイトのデータ7)を参考に, 単位面積・

\section{表-1 ランダムウォーク粒子追跡法に用いたパラメータ}

\begin{tabular}{lr}
\hline 縦・横分散長 $\alpha_{L}, \alpha_{T}(\mathrm{~m})$ & $0.02,0.005$ \\
遅延係数 $R(-)$ & 1.0 \\
時間ステップ $\Delta t$ (day) & 1.0 \\
井戸半径 $r(\mathrm{~m})$ & 0.5 \\
粒子数 $N$ & $5 \times 10^{4}$ \\
\hline
\end{tabular}

単位深さあたり, $1 \mathrm{day}^{-1}$, あるいは, $3 \mathrm{day}^{-1}$ の揚水 量 $Q$ を設定した。サイトの状態を反映して， $x=0 \mathrm{~m}$ と $x=270 \mathrm{~m}$ の面を 0.05 の動水勾配となる水頭境界, $y=0 \mathrm{~m}$ と $y=160 \mathrm{~m}$ の面を不透水境界に設定し, 有限要 素解析により水頭分布を導出した. 次に, 間隙率 $n_{p}$ は対 象空間内で一定と見なして，0.35に設定し，Darcy則に より実流速ベクトルvの空間分布を求めた.

$$
\boldsymbol{v}=-K(\boldsymbol{x}) \nabla h / n_{p}
$$

\section{（3）ランダムウォーク粒子追跡法と集粒域推定}

ランダムウォーク粒子追跡法 (Random Walk Particle Tracking: 以下，RWPTと記す）は溶質に見立てた大量の 粒子群を領域内に発生させて, 各粒子の質量ならびに位 置ベクトルの空間分布変動を時系列で追跡するラグラン ジュ的手法である67). 粒子追跡過程における主たる移 動経路はドリフト成分と確率的分散成分から構成され,

$$
\boldsymbol{X}_{p}(t+\Delta t)=\boldsymbol{X}_{p}(t)+(\boldsymbol{v}+\nabla \cdot \boldsymbol{D}) \Delta t / R+\boldsymbol{B} \mathbf{\Xi} \sqrt{\Delta t}
$$

となる ${ }^{7)}$.ここに, $\boldsymbol{X}_{p}(t)$ は時刻 $t$ における粒子位置べク トル, $\Delta t$ は時間増分, $R$ は遅延係数, 注平均 0 , 分散 1 の正規乱数ベクトル, $\boldsymbol{D}$ は分散係数テンソルであり,

$$
\boldsymbol{D}=\alpha_{T}|\boldsymbol{v}| \boldsymbol{I}+\left(\alpha_{L}-\alpha_{T}\right) v_{i} v_{j} /|\boldsymbol{v}|, \quad i, j=1,2
$$

である ${ }^{12)}$ 。ここに， $v_{i}$ は実流速成分， $|\boldsymbol{v}|$ は実流速ノル ム，Iは単位マトリクス，Bは変位マトリクスであり,

$$
\boldsymbol{B}=\left(\begin{array}{cc}
\sqrt{2 \alpha_{L} v_{1}^{2} /(|\boldsymbol{v}| R)} & 0 \\
0 & \sqrt{2 \alpha_{T} v_{1}^{2} /(|\boldsymbol{v}| R)}
\end{array}\right)
$$

である。また， $\alpha_{L}$ は縦分散長， $\alpha_{T}$ は横分散長であり， 文献7を基にそれぞれ $0.02 \mathrm{~m}, 0.005 \mathrm{~m}$ に設定した. 対象 サイトの不均質度は低いため, 文献值を分散長として採 用した. 本解析では, 取水井の位置に仮想的な井戸半径 $r$ を設け，ある時刻 $t$ から $t+\Delta t$ 間の粒子移動で描く線分が 取水井位置を中心とした半径 $r$ のと交わる, または接 する場合を該当粒子の取水井流入と判定した。 また，遅 延係数は1，時間ステップは1日とした．表-1にRWPTに 用いたパラメータを記す。

RWPTの例として, 領域内の任意地点に初期配置した $8 つ$ 粒子の移動経路を図-2に示寸．対象場の揚水量は 3 day $^{-1}$ であり, 透水係数分布は生成した 30 種類のリアラ 


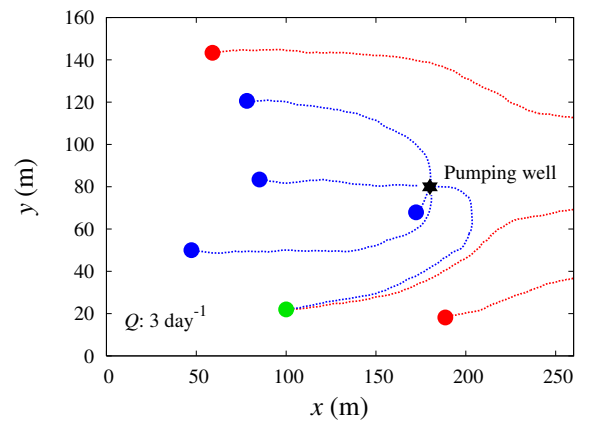

図-2 粒子群の移動経路の一例. 緑色の部分には2つの粒子がある.

イゼーションの1つを採用している．青色の粒子は移流分 散しながら取水井に到達するのに対して, 赤色の粒子は 取水井一流入せずに領域外一移動する様子がわかる。つ まりは, 粒子の初期位置に応じて取水井一の到達状態は 異なることを示している. しかしながら，緑色の粒子は 同一の初期位置にある2つの粒子を表しており，一方は 取水井一流入し, 他方は領域外一移動している. これは 分散の効果により, 輸送経路が顕著に異なった結果であ り, 分散現象により初期位置だけでは取水井一の到達状 態は決まらないことを示唆している，さらに，透水場の 透水係数分布が異なると流線は透水係数分布に依存して 変化するため, 取水井一の到達の有無についても影響が 及ぶことになる。したがって，取水井に溶質が流入する 領域，すなわち，集粒域は一意には定まらないと言える.

そこで本研究では, 確率的に集粒域の分布を推定する ため, 第一のステップとして, 対象領域に一様乱数を用 いて粒子を大量に配置し，RWPTにより溶質輸送を解析 することですべての粒子に対して取水井への到達の有無 を求める手段を講じた. 領域の境界部を避けて, $x$ 方向 は $10 \mathrm{~m}$ から $250 \mathrm{~m}, y$ 方向は $10 \mathrm{~m}$ から $150 \mathrm{~m}$ の $33600 \mathrm{~m}^{2}$ の範囲内に $N$ 個の粒子を初期配置させ，すべての粒子が 取水井に到達するか, 領域外一移行するまで, 全粒子の 移流分散挙動をRWPTにより解析した. 生成した 30 種類 の透水場に対して同様の過程を経ることで， $30 \times N$ 個の 粒子に対して, 取水井一到達する粒子と領域外一移動す る粒子を判別した．便宜上，取水井へ到達した粒子を到 達粒子, 領域外へ移動した粒子を非到達粒子と記す。

すべての粒子に判別フラグを付すことで，ある座標 $(x, y)$ に位置する粒子数 $n$ とその中で取水井一到達する粒 子数 $m$ の除算 $m / n$ により, 当該地点が集粒域と成り得る 確率を 0 から1の範囲で求めることができる. しかしなが ら, 図-2の緑色の粒子のように, 同一の座標に繰り返し て粒子が配置される可能性は極めてゼロに近く, 点座標 での集粒域推定は現実的ではない。実際問題として, 特 定の地“点”を潜在的な污染源と見なすような予測・予見 はせず，任意の“面”を污染源に想定した上で揚水規模や 揚水位置などの浄化策・回避策を講じるのが一般的であ る1). そこで第二のステップとして, 有限要素とは別に, 仮想格子を導入することで集粒域確率を面推定した.

図-3に示すように, 領域全体を任意幅 $\Delta S$ 仮想格子で

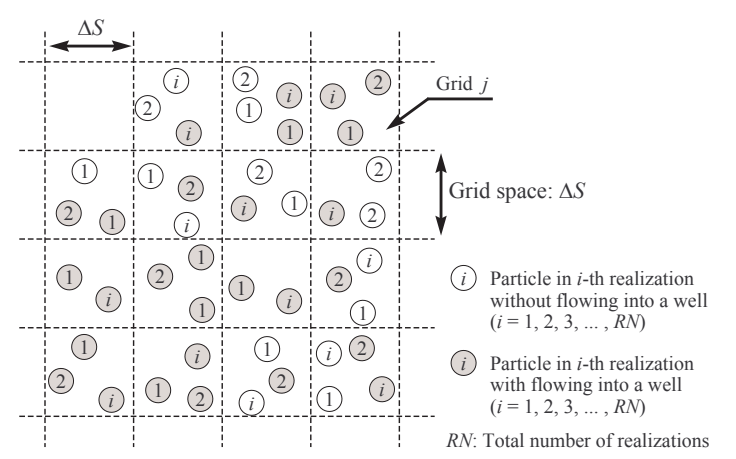

図-3 仮想格子の設定

覆い, 単一のリアライゼーションiで初期配置した全粒 子を格子内に収めた。 また, RWPTの解析結果に基づき, 到達粒子と非到達粒子を判別することにより, 既定の格 子 $j$ に収まる粒子数 $n_{i}^{j}$, ならびに, 到達粒子数 $m_{i}^{j}$ を定め た. 同様の過程を30リアライゼーションすべてに繰り返 して重㸚合わせることにより, 格子 $j$ の集粒域確率 $P^{j}$ を

$$
P^{j}=\sum_{i=1}^{R N} m_{i}^{j} / \sum_{i=1}^{R N} n_{i}^{j}
$$

と定義し, すべての格子について集粒域確率を求めた. ここに, RNはリアライゼーション総数であり, 本解析 では30である，たとえば，16分割した図-3では，左下と 右上の格子の確率は 1 , 右下は 0.5 , 左上は0である.

前述のように, $33600 \mathrm{~m}^{2}$ の範囲内に $N$ 個の粒子を初期 配置するため, 幅 $\Delta S$ の格子には, 理論上,

$$
\frac{N}{33600} \cdot \Delta S^{2} \cdot R N
$$

の粒子が存在する. 仮想格子の導入は集粒域確率を推定 したい解像度に応じて $\Delta S$ を任意に変更できる特徴を有し ているものの，過度に大きい，あるいは，小さい設定は 現実的ではないため, $\Delta S=2 \mathrm{~m}$ を基準に設定した。ま た, 集粒域確率を推定する際には, 各格子内に収まる粒 子数が少ないと信頼性に影響するため, 確率上, 100個 以上の粒子が存在するように, 初期粒子総数 $N$ を定める こととした. したがって, 単一のリアライゼーションに て発生する粒子数 $N を 5 \times 10^{4}$ に設定した.

\section{3. 結果と考察}

\section{(1) 集粒域と不確実定数}

不均質度 $\sigma_{\ln K}^{2}=0.151 \mathrm{~m}^{2} / \mathrm{day}^{2}$ を有する対象サイトに て1 day ${ }^{-1}$ の揚水量を考慮した透水場に対する集粒域分 布の推定結果を図-4に示寸. また, 揚水量を $3 \mathrm{day}^{-1}$ と して考慮した場に対する集粒域分布の推定結果を図-5に 示寸. 図-4と図-5ともに，格子間隔に応じた推定結果の 差異を可視化するため, 格子間隔 $\Delta S$ を $2 \mathrm{~m}, 3 \mathrm{~m}, 4 \mathrm{~m}$ に 変えた 3 種類の推定結果を示している. 揚水に伴って取 水井一向から地下水流れの領域が存在するため, 取水井 より上流側において, 図-4ではy座標60 mから100 mの範 

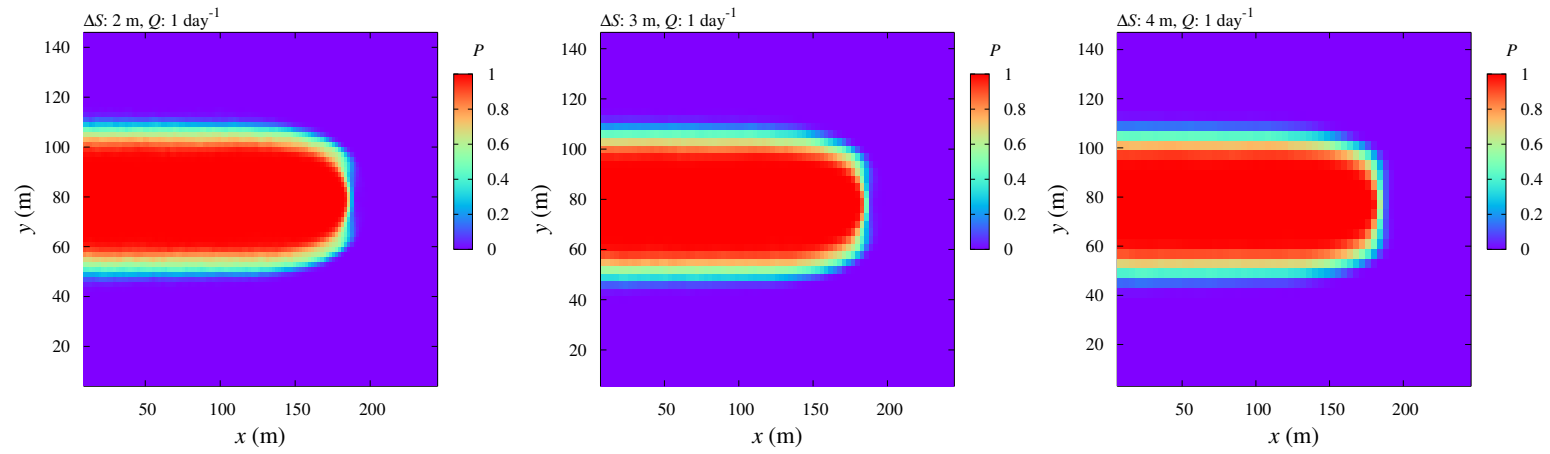

図-4 低い揚水量条件での格子間隔に応じた集粒域分布の推定結果
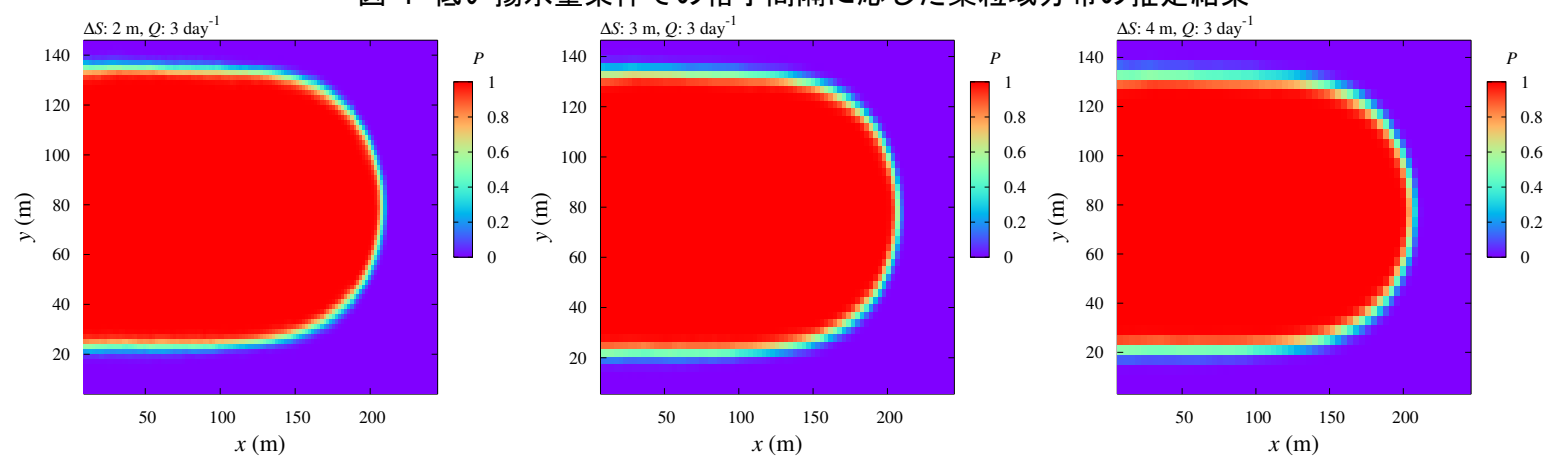

図-5 高い揚水量条件での格子間隔に応じた集粒域分布の推定結果

囲，図-5ではy座標20 mから $130 \mathrm{~m}$ の範囲ではほとんどの 格子で確率は1となっている。 また，確率の高い範囲か ら外側に向かって徐々に確率は低下していき，確率ゼロ に至る傾向は揚水量に関わらず共通の結果であり，既往 の研究傾向 ${ }^{2)}$ とも合致する.

各格子の集粒域確率 $P^{j}$ につて図-4と図-5を比較する と，低い揚水量の場の方が $P^{j} \neq 0 か つ P^{j} \neq 1$ となる格子が 領域に占める割合は大きい。この点を定量化するため, 集粒域確率 $P^{j}=1$ となる面積を $A_{c}, P^{j} \neq 0$ か $P^{j} \neq 1$ とな る面積を $A_{u}$ として，該当格子を抽出し，格子間隔に応じ た $A_{c}$ と $A_{u}$ の変化を図-6に示す．揚水量の高い場の方が広 い範囲から溶質を回収できるため，揚水量に呼応して面 積 $A_{c}$ は大きくなる，また，格子間隔が大きくなるほど, $P^{j}=1$ となる格子は少なくなり, 逆に, $P^{j} \neq 0 か つ P^{j} \neq 1$ となる面積 $A_{u}$ の值が上昇する。 このとき，低揚水量の場 の方が高揚水量の場よりも面積 $A_{u}$ は広くなる点は特徵的 であり，本解析領域では，低揚水量の場ほど確率が0か1 に定まらない範囲が広く存在することを示している.

集粒域確率について吟味するため, 面積 $A_{u}$ と面積 $A_{c}$ の 比 $A_{u} / A_{c}$ を不確実係数 $U F$ として導入し, 図-6の結果を基 に，格子間隔に応じた不確実係数の変化を図-7に緑色で 示す．横軸には格子間隔を領域 $x$ 方向距離 $L=270 \mathrm{~m}$ で除 した無次元数を設定している．揚水量に関わらず，格子 間隔が増加するにつれて，不確実係数は増加し，低揚水 場の不確実係数の方が大きくなる．また，高揚水量の場 ほど取水井方向に向く流速成分は多くなり，低揚水量の 場よりも多くの粒子が取水井に流入する6)ことから，流 速ベクトルの方向や大きさ，さらには溶質分散の効果が 複合することで集粒域確率，特に， $P^{j} \neq 0 か つ P^{j} \neq 1$ と

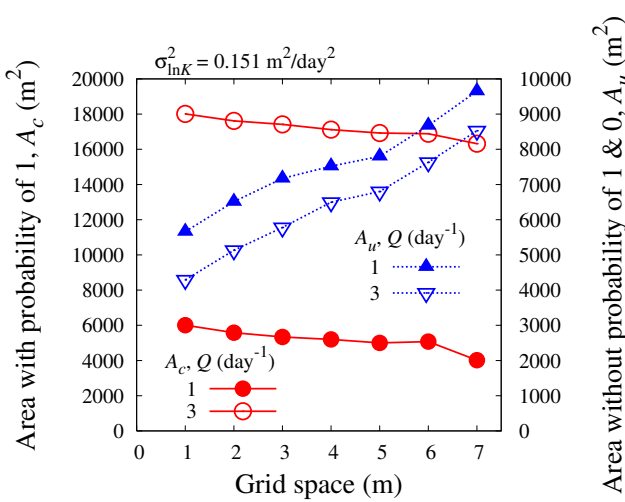

図-6 格子間隔に応じた集粒域面積の相違

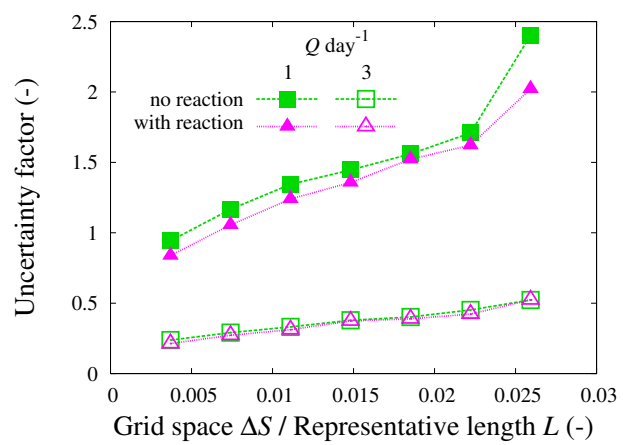

図-7 無次元化した格子間隔と不確実係数の関係

なる範囲に影響を及ぼしていると推察される，集粒域の 確率分布は格子間隔依存ではあるものの，任意の格子間 隔で集粒域を推定できることは本手法の利点と言える.

污染物質の揚水処理や到達予測では，集粒域の空間分 布に加えて, 取水井に至るトラベルタイム推定が重要と なる1)。トラベルタイムを推定するため，本手法では，到 達粒子の初期位置から取水井までのトラベルタイムを記 

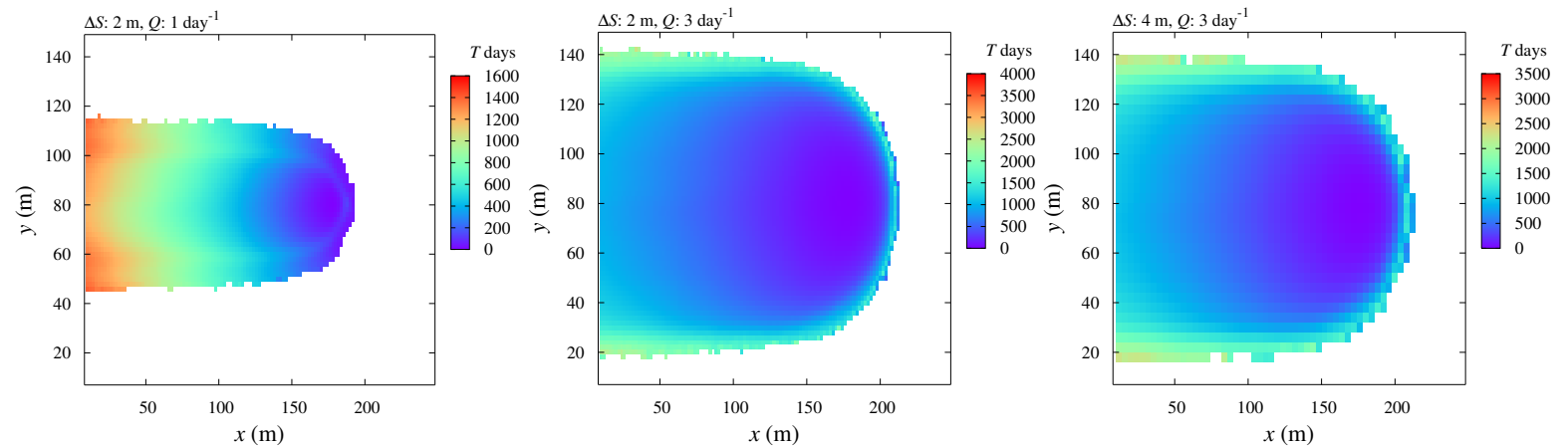

図-8 揚水量や格子間隔に応じたトラベルタイム分布の推定結果
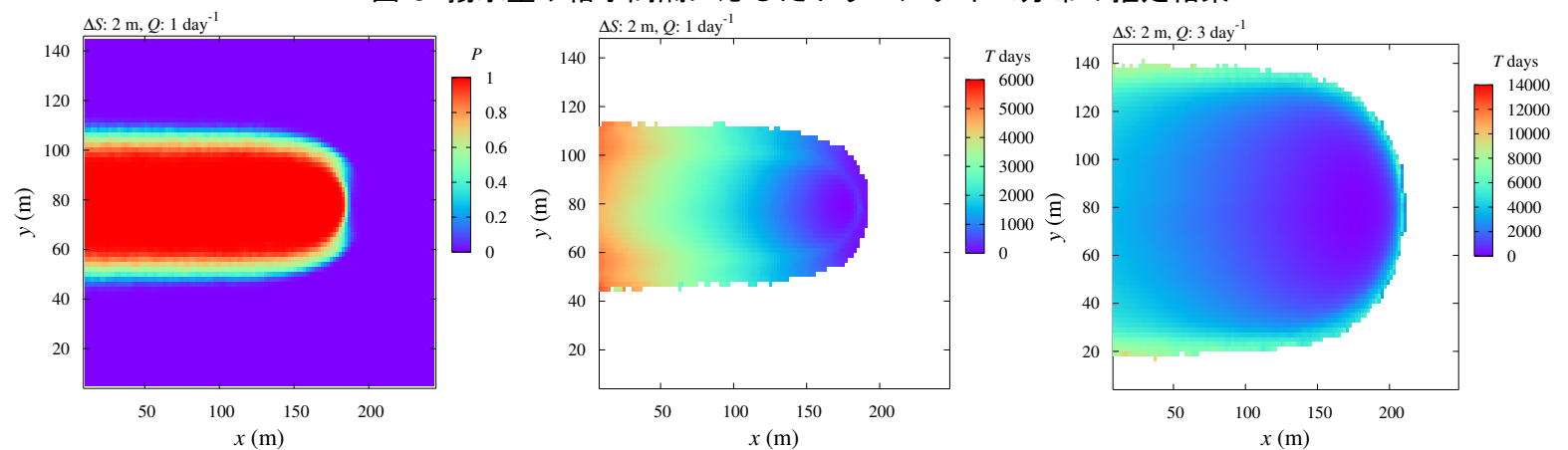

図-9 遅延係数のばらつきを考慮した場に対する集粒域分布とトラベルタイム分布の推定結果

憶した。また，集粒域推定に用いた格子を再度利用して， 格子内の到達粒子の平均トラベルタイムを該当格子のト ラベルタイム $T$ とすることで，トラベルタイムの空間分布 推定を可能にした. 図-8に代表的な結果として, 揚水量 や格子間隔に応じたトラベルタイムの空間分布の推定結 果を示す．取水井よりも上流側ほど，また同一 $x$ 座標のう ち, 取水井からの幾何距離が長い地点ほどトラベルタイ ムは長くなる一般的な結果が得られており，推定結果は 妥当であると判断される. したがって，本手法では，任 意の格子に位置する污染物質が取水井へ到達する確率と 到達するまでの予測時間を推定することが可能である.

\section{（2）化学的不均質性の影響}

一般的に，帯水層内の溶質輸送過程では，物質と土粒 子間で吸脱着反応が生じる ${ }^{12)}$ た, 帯水層管理の一環と して集粒域確率を推定する場合, 吸脱着を反映した化学 的不均質モデルを扱うことは十分に考えられる. 本解析 では, 透水係数と遅延係数の相関モデル13)を採用し,

$$
R(\boldsymbol{x})=1+\rho_{b} K_{d g} \exp (\beta(\ln K(\boldsymbol{x})-\langle\ln K\rangle)) / n_{p}
$$

により, 透水係数のリアライゼーションに応じた遅延係 数の空間分布を生成した. ここに, $\langle\ln K\rangle$ は透水係数の幾 何平均である. 文献を参考にして, 分配係数の幾何平均 $K_{d g}$ は $0.526 \mathrm{~m}^{3} / \mathrm{Mg}$, 乾燥密度 $\rho_{b}$ は $1.5 \mathrm{Mg} / \mathrm{m}^{3}$ とした7). また, 定数 $\beta$ は分配係数と透水係数の相関強さを表寸定数 である. 十分な解像度で透水係数の夕ならず分配係数を 求めることは現実的には難しいことから, 文献13)を参考 に定数 $\beta$ は平均 -0.2 , 分散 0.24 正規分布となるように, ラテンハイパーキューブ法 ${ }^{14)} に よ り 30$ 個生成し, 透水係
数のリアライゼーションごとに異なる $\beta$ を設定した.つま りは，定数 $\beta$ を正規確率変数と考えることで, 種々の相 関強さを有する化学的不均質場となるように配慮した.

化学的不均質性を考慮した場合の集粒域確率の分布, ならびに, トラベルタイムの分布結果を図-9に示寸. 化 学的不均質性を考慮した場の平均遅延係数は3.25であり, 図-4や図-8の結果と比較して, トラベルタイムの数值が 遅れに対応して増えているものの，分布形状には際立っ た差異はない，また，図-7に紫色で示すように，格子間 隔と不確実係数の関係は化学的不均質性を考慮していな い緑色の結果とほぼ同じである。これは遅延係数のバラ ツキが取水井に至る溶質輸送経路を大幅に変化させる効 果を有していないことに起因すると考えられ，対象サイ 卜のように物理的不均質度の低い場においては, 化学的 不均質性は集粒域にあまり影響せず，平均的な遅れを加 味したトラベルタイム分布になる.

\section{(3) 透水係数の不均質度合いの影響}

対象サイトの透水係数分布の幾何分散は $0.151 \mathrm{~m}^{2} / \mathrm{day}^{2}$ であり，不均質度としては比較的低いサイトである。 そ こで, 透水係数の幾何分散を $1.0 \mathrm{~m}^{2} / \mathrm{day}^{2}$ にして, 30 リ アライゼーションの模擬透水場を生成することで不均質 度を上げた場に対して本手法を適用した。 図-10に，2 m の格子間隔にて得られた集粒域分布とトラベルタイムの 推定結果を示寸，不均質度が高くなることにより，集粒 域の推定確率のバラツキは大きくなり, トラベルタイム の空間分布は図-8に示寸低不均質度の場よりもいびっな 形状を呈している。

不均質度の変化を評価するため, 図-11に格子間隔と 

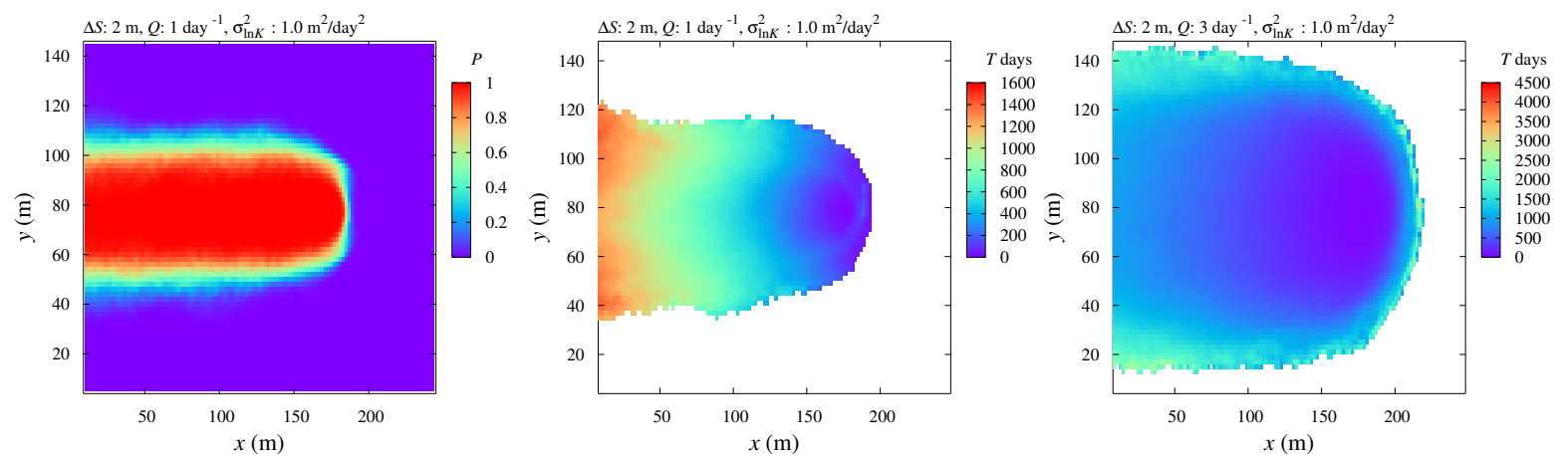

図-10 不均質性の高い場に対する集粒域分布とトラベルタイム分布の推定結果

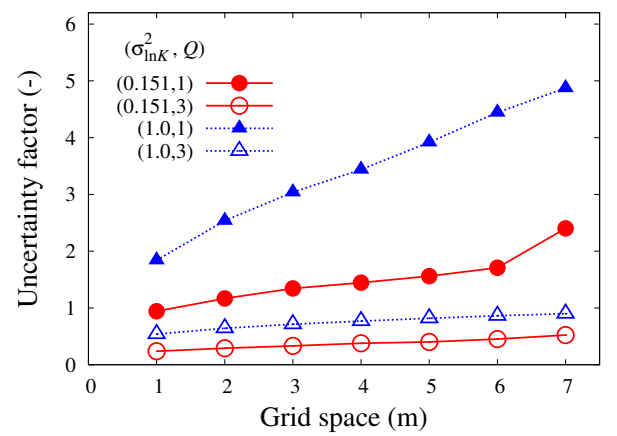

図-11 不均質度に応じた格子間隔と不確実係数の関係

不確実係数の関係を不均質度 $0.151 \mathrm{~m}^{2} / \mathrm{day}^{2}$ のケースと 合わせてプロットする. 格子間隔に依存して不確実係数 は二倍から数倍大きくなっており, 透水係数の不均質度 合いが増すことにより, 溶質輸送経路は大きく変化し, 到達粒子の数に強く影響を及ぼすことがわかる.

\section{4. 結論}

本研究では, 取水井に溶質が流入する領域を集粒域と 定義し，ランダムウォーク粒子追跡法と格子の重ね合わ せを用いた集粒域・トラベルタイム分布の確率的推定方 法を考案した. オランダのサイトを対象として, 透水係 数の空間分布を地球統計学的に30リアライゼーション生 成し, 揚水量条件や不均質条件を変えた透水場に本手法 を適用した。また，集粒域の評価手段として，各格子の 取り得る確率に基づいた不確実係数を導入した。 その結 果，高い揚水量の場ほど，集粒域確率が 0 より大きく 1 末 満となる面積が小さくなり, 不確実係数は小さく評価さ れた. また, 化学的不均質性はトラベルタイムの数值に のみ影響を及ぼし，集粒域の分布にはあまり影響しない ことがわかった. さらに，透水係数のバラツキの増加は 不確実係数の上昇につながる結果を得た。

今後の課題として, 透水係数分布の相関長の影響や複 数取水に対する集粒域推定が挙げられる.

\section{参考文献}

1) U.S. Environmental Protection Agency: Design guidelines for conventional pump-and-treat systems, U.S. Environmen- tal Protection Agency, EPA/540/S-97/504, 38p., 1997.

2) Feyen, L., Ribeiro Jr., P.J., Gómez-Hernández, J.J., Beven, K.J. and De Smedt, F.: Bayesian methodology for stochastic capture zone delineation incorporating transmissivity measurements and hydraulic head observations, J. Hydrol., 271, pp.156-170, 2003.

3) Riva, M., Guadagnini, A. and De Simoni, M.: Assessment of uncertainty associated with the estimation of well catchments by moment equations, Adv. Water Resour., 29, pp.676-691, 2006.

4) Kunstmann, H. and Kinzelbach, W.: Computation of stochastic wellhead protection zones by combining the firstorder second-moment method and Kolmogorov backward equation analysis: J. Hydrol., 237, pp.127-146, 2000.

5) Tosco, T., Di Molfetta, A. and Sethi, R.: Automatic delineation of capture zones for pump and treat systems: a case study in Piedmont, Italy, Ground Water Monitor. Remedi., 30(2), pp.46-52, 2010.

6) 井上一哉, Uffink, G.J.M., 田中勉 : 粒子追跡法による集 水域の時間変動と粒子捕獲確率に関する評価, 水工学論 文集, 53, pp.523-528，2009.

7) Uffink, G.J.M.: Analysis of dispersion by the random walk method, Ph.D Dissertation, TU-Delft, 150p., 1990.

8) Ghori, S.G., Heller, J.P. and Singh, A.K.: An efficient method of generating random permeability fields by the source point method, Math. Geol., 25(5), pp.559-572, 1993.

9) Deutsch, C.V. and Journel, A.G.: GSLIB: Geostatistical software library and user's guide, Oxford University Press, 340p., 1992.

10) 齋藤雅彦, 高山裕介, 中川啓 : 数值シミュレーションに よる不均一地盤内の塩水侵入挙動に関する研究, 土木学 会論文集B1（水工学），67(4), pp.595-600，2010.

11) Hubbard, S.S. and Rubin, Y.: Hydrogeological parameter estimation using geophysical data: a review of selected techniques, J. Contam. Hydrol., 45(1-2), pp.3-34, 2000.

12) Bear, J.: Dynamics of fluids in porous media, Dover Publications, 764p., 1972.

13) Tompson, A.F.B.: Numerical simulation of chemical migration in physically and chemically heterogeneous porous media, Water Resour. Res., 29(11), pp.3709-3726, 1993.

14) McKay M.D., Beckman R.J. and Conover W.J.: A comparison of three methods for selecting values of input variables in the analysis of output from a computer code, Technometrics, 21(2), pp.239-245, 1979.

（2014.9.30受付） 